\title{
Recovering Ability of Upland and Rainfed Lowland Rice Varieties against Rice Tungro Disease
}

\author{
M T Khatun 1,, M A Latif ${ }^{1}$, M M Rahman², M Hossain ${ }^{1}$, T H Ansari ${ }^{1}$, B Nessa ${ }^{1}$ \\ M A I Khan ${ }^{1}, \mathrm{M} \mathrm{A} \mathrm{Ali}^{1}$ and M M Hanafi ${ }^{3}$
}

\begin{abstract}
Rice tungro is the most destructive and widespread among virus diseases found in almost all rice growing areas. In susceptible varieties, it causes $100 \%$ yield loss under favourable environmental conditions. Control of tungro disease by chemical applications is not effective and eco-friendly. Development of resistant variety against tungro is also difficult, because it is necessary to develop resistance either to the insect vector or to the virus or to the both. Identification of varieties with recovering ability will facilitate farmers to cultivate rice in tungro endemic areas. Bangladesh Rice Research Institute released six upland and eight rainfed lowland rice varieties, which were tested to evaluate their recovering ability against tungro disease. The test varieties including susceptible and resistant checks were artificially inoculated by viruliferous vector (Green leafhopper, Nephotettix virescens) of ten days after seeding in net house condition. Among the tested varieties BR26, BRRI dhan33 and BRRI dhan 40 were the most susceptible and showed high infection rate against tungro disease. BRRI dhan37 and BR8 showed the highest recovering ability in rainfed lowland and upland rice, respectively, with the lowest yield reduction compared to the resistant check Kumragoir, which could be used in tungro endemic areas. From these investigations, all the tested varieties expressed distinct tungro disease symptoms after three weeks of inoculation. With the advancement of plant growth, varieties BR8 and BRRI dhan37 recovered from tungro syndrome due to their genetic makeup consisting tolerance potentiality showed better yield, while other varieties like BRRI dhan33 and BRRI dhan40 did not produce any grain yield.
\end{abstract}

Key words: Tolerance, Aus, Aman, rice tungro virus

\section{INTRODUCTION}

Rice (Oryza sativa L.) is the most used cereal grain in the diet of more than three billion people in the world. Seventy-two diseases affect rice (Bergonia, 1978) and 22 of them are caused by virus and virus like microorganisms of which rice tungro is the most important $(\mathrm{Ou}, 1984)$. It is the most serious and wide spread disease occurring in the rice growing countries like Bangladesh (Miah, 1973), India (John, 1968), Malaysia (Ou et al., 1965) and the Philippines (Rivera and Ou, 1965). Rice tungro disease (RTD), caused by the co-infection of rice tungro bacilliform virus (RTBV) and rice tungro spherical virus (RTSV). Both RTBV and RTSV are transmitted in a semi persistent manner by the green leafhopper (GLH), Nephotettix virescens (Distant), and some other leafhopper species (Hibino et al., 1979; Hibino, 1983). For a susceptible variety without any recovery ability, rice tungro disease (RTD) may cause $100 \%$ infection and resulting in total yield loss under favourable condition (BRRI, 1983). The disease remains one of the major threat to sustainable rice production in many rice growing countries. It is one of the major constraints in rice production, particularly in the upland and rainfed ecosystems (Miah, 1984; Latif et al., 2011). The lack of resistant genes to RTBV- the causal agent of tungro-disease makes it even more difficult to manage RTD (Dahal et

\footnotetext{
${ }^{1}$ Plant Pathology Division, Bangladesh Rice Research Institute, Joydebpur, Gazipur 1701, Bangladesh. ${ }^{2}$ Former Head and Chief Scientific Officer, Plant Pathology Division, Bangladesh Rice Research Institute. ${ }^{3}$ Laboratory of Plantation Crops, Institute of Tropical Agriculture and Food Security, Universiti Putra Malaysia, 43400, UPM Serdang, Selangor, Malaysia. *Corresponding author's E-mail: tuhinabrri17@gmail.com
} 
al., 1992). Therefore, sustainable strategies are urgently required for the management of RTD.

The use of resistant or varieties with recovering ability is believed to be the most effective method for controlling rice tungro disease as killing the vector with insecticides to control this disease is not very effective and may cause environmental and health hazards (Latif et al., 2011). Several rice germplasm sources resistant or tolerant to RTD have been used to improve rice cultivars in endemic areas (Khush et al., 2004), although a distinction between resistance to GLH and to tungro viruses in some rice genotypes is still unclear (Shibata et al., 2007; Zenna et al., 2008). Some traditional rice cultivars and wild Oryza spp. have been used for the improvement of cultivars tolerant or resistant to RTD. Advanced breeding lines derived from Utri Merah consistently showed low infections with both RTBV and RTSV in several field trials (Cabunagan et al., 1999). Kachamota and ARC 11554 were found resistant to tungro in Malaysia and Indonesia. Moreover, ARC 11554 was found resistant to tungro in many countries (Miah, 1984). Due to evolution of new strains, varieties of high recovering ability may also lose its potentiality. Therefore, it is pertinent to evaluate existing rice varieties having recovering ability, which are intensively cultivated in the farmer's field. Present studies were conducted to identify the varieties, which have high recovering ability against tungro disease and these might be used to cultivate under rainfed upland and lowland ecosystems in tungro endemic areas. The varieties which recovered from disease will also be used as parents for hybridization programme to develop tungro resistant/tolerant varieties.

\section{MATERIALS AND METHODS}

\section{Site and design}

The experiments were conducted at net house and field of Plant Pathology Division, Bangladesh Rice Research Institute (BRRI), Gazipur, during the period from March to June 2008 for upland varieties and June to October
2008 for lowland rice varieties. In the field, the experiments were set up in randomized complete block design (RCBD) with three replications.

\section{Plant materials}

A total of 16 rice varieties including six uplands, eight lowlands, one resistant and one susceptible check were used in these studies (Table 1). The varieties were selected on the basis that they were the promising upland and rainfed lowland varieties for cultivation in the farmers field. The Kumragoir is a local rice variety and highly resistant, while Purbachi is a highly susceptible variety against tungro disease (Latif et al., 2011). The seeds of all varieties were collected from Adaptive Research, and Genetic Resources and Seed Division, BRRI, Gazipur, Bangladesh.

\section{Seedling growth}

Sundried seeds of each variety were placed into petridish on one piece of filter paper. The filter paper was soaked with water to provide moisture for seed germination. The petridishes were kept in room temperature and water was added everyday to maintain moisture. Just after germination, seeds were sown in line in trays. One line was allocated for each variety and each line consisted of about 50-60 seeds. Each variety was sown in three trays. After ten days, two trays were used for inoculation and the third tray was used as control.

\section{Inoculation of seedlings (at net house)}

Initially GLHs were allowed to feed on 45-to 60-day-old infected source plants (affected by tungro disease) with distinct symptoms for 2 to 3 days. Ten-day-old seedlings of two trays of each variety were inoculated by viruliferous GLH for 24 hrs in wood-net made cage in net house. To ensure proper inoculation at least 3-4 viruliferous GLH per test plant were introduced into the cage. To ensure enough inoculum for each seedling the GLHs used for inoculation inside the case were disturbed several times during the inoculation access period. Three weeks after inoculation, symptoms appeared and the seedlings were scored based on visual 
Table 1. Rice varieties of upland and rainfed lowland condition, 2008.

\begin{tabular}{lcc}
\hline Variety & Eco-type & $\begin{array}{c}\text { Reaction against } \\
\text { tungro }\end{array}$ \\
\hline BR8 & Upland & Upland \\
BR26 & Upland & Unknown \\
BRRI dhan27 & Upland & Unknown \\
BRRI dhan42 & Upland & Unknown \\
BRRI dhan43 & Upland & Unknown \\
BRRI dhan48 & Upland & Unknown \\
& Lowland rainfed & \\
Purbachi & Upland/lowland & Susceptible check \\
Kumragoir & Upland/lowland & Resistant check \\
BRRI dhan33 & Lowland & Unknown \\
BRRI dhan34 & Lowland & Unknown \\
BRRI dhan37 & Lowland & Unknown \\
BRRI dhan38 & Lowland & Unknown \\
BRRI dhan39 & Lowland & Unknown \\
BRRI dhan40 & Lowland & Unknown \\
BRRI dhan41 & Lowland & Unknown \\
BRRI dhan46 & Lowland & Unknown \\
\hline & &
\end{tabular}

observation. Healthy checks were used to compare with diseased one.

\section{Field experiment}

The inoculated seedlings along with the control plants of each variety were transplanted in the field of Plant Pathology Division, BRRI. For each variety $1 \mathrm{~m} \times 1 \mathrm{~m}$ plot was used. Row to row and plant to plant distance was maintained as $20 \mathrm{~cm}$. The upland varieties were planted on high land with almost no supply of irrigation (limited irrigation was supplied only when needed) during March to June 2008. The rainfed varieties were planted when there was adequate rainfall to ensure water supply for plants during June to October 2008. Management practices such as weeding, fertilization were followed by BRRI recommendations (BRRI, 2000).

\section{Data collection and statistical analysis}

Data were collected on seedling infection (symptom), plant height $(\mathrm{cm})$, number of tillers/plant, number of panicles/plant, panicle length $(\mathrm{cm})$, number of filled grains/panicle and yield/plant (g) (Table 2). Seedling infection score was recorded from 10 inoculated plants by visual observation. From each replication five plants were selected randomly to record data for plant height, number of tillers/plant, number of panicles/plant, panicle length $(\mathrm{cm})$, number of filled grains/panicle and yield/ plant (g). The recovering ability was measured from the inoculated varieties by all the yield contributing parameters, implied how the infected plants showed their potentiality to provide better yield after being infected by tungro virus. The analysis of variance (ANOVA) which expressed the main interaction effect was analyzed by Statistical Analysis System (SAS version 9.2) for all quantitative traits. The Least Significant Difference (LSD) was performed for mean comparison when varietal differences were found significant at $p=0.05$ level of probability.

\section{RESULTS}

\section{Upland rice}

Recovering data. The morphological and yield traits varied significantly among the tested varieties in the present study (Table 3). The seedling infection by RTD was the highest in variety BRRI dhan27 (93.39\%) followed by BRRI dhan43 (91.91\%) and BR26 (91.59\%) which were higher than the susceptible check Purbachi (90.39\%) (Table 4). The resistant check Kumragoir did not show any symptoms of tungro disease in inoculated plants. The lowest seedling infection was found in variety BR8 (76.74\%). All the eight varieties showed higher plant height $(\mathrm{PH})$ in control plants than inoculated one. Among tested varieties the highest $\mathrm{PH}$ was recorded for the variety BR8 $(45.76 \mathrm{~cm})$ in inoculated plants, however in control plants this value was recorded as $92.13 \mathrm{~cm}$, a reduction of $50.33 \%$ in this variety (Fig. 1). The lowest PH was observed in the variety BR26 $(33.71 \mathrm{~cm})$ in treated plants, while in control plants it was 
Table 2. List of traits and their evaluation method.

\begin{tabular}{ll}
\hline Trait & Evaluation method \\
\hline $\begin{array}{l}\text { Seedling infection (\%) } \\
\text { Plant height }(\mathrm{cm})\end{array}$ & $\begin{array}{l}\text { The yellow/orange yellow, twisted leaves were rated by visual observation } \\
\text { Plant height was measured during harvesting from base of the plant to tip } \\
\text { of the tallest leaf blade }\end{array}$ \\
Number of tillers/plant (no.) & $\begin{array}{l}\text { Total number of tillers were counted from each plant where secondary and } \\
\text { tertiary tillers were also included }\end{array}$ \\
Number of effective tillers/plant (no.) & $\begin{array}{l}\text { Effective tillers were counted as those tillers which bear panicle. } \\
\text { The panicle length was recorded as the distance between the top most node } \\
\text { of culm and the apex of panicle excluding awn. }\end{array}$ \\
Number of filled grains/panicle (no.) & $\begin{array}{l}\text { Only the fertilized filled grains or fully developed spikelets were counted } \\
\text { from each panicle of a plant and average of all panicles were recorded. }\end{array}$ \\
Tield/plant $(\mathrm{g})$ & Total filled grains of a plant were weighed by an electric balance.
\end{tabular}

Table 3. Mean squares of analysis of variance for morphological and yield contributing characters studied in inoculated and uninoculated plants in upland rice varieties.

\begin{tabular}{lcccccccc}
\hline SV & df & SI & PH & NT/H & NP/H & PL & FG/P & Y/P \\
\hline Block (B) & 2 & $27.45^{\text {ns }}$ & $2245.71^{*}$ & $3.66^{\text {ns }}$ & $4.12^{\text {ns }}$ & $3.48^{\text {ns }}$ & $520.75^{\text {ns }}$ & $0.80^{\text {ns }}$ \\
Variety (V) & 7 & $1499.68^{* *}$ & $1011.27^{\text {ns }}$ & $68.36^{* *}$ & $40.20^{* *}$ & $37.65^{* *}$ & $2862.67^{* *}$ & $647.72^{* *}$ \\
Treatment (T) & 1 & $71251.98^{* *}$ & $23392.44^{* *}$ & $0.73^{\text {ns }}$ & $185.81^{* *}$ & $92.66^{* *}$ & $6143.14^{* *}$ & $1055.25^{* *}$ \\
Var*Trt & 7 & $1499.68^{* *}$ & $83.02^{\text {ns }}$ & $4.53^{\text {ns }}$ & $5.62^{\text {ns }}$ & $1.16^{\text {ns }}$ & $1321.96^{* *}$ & $60.49^{* *}$ \\
Error & 30 & 44.66 & 414.14 & 4.66 & 5.56 & 1.37 & 365 & 0.68 \\
\hline
\end{tabular}

$\mathrm{SV}$, source of variation; $\mathrm{df}$, degree of freedom; SI, \% seedling infection; $\mathrm{PH}$, plant height (cm); NT/H, total number of tillers plant $^{-1}$, NP/H, number of panicles/hill; PL, panicle length; FG/P, number of filled grains/panicle; Y/P, yield/plant(g) *Significant at $5 \%$ level; ** highly significant at $1 \%$ level; ${ }^{\text {ns }}$ non significant.

Table 4. Morphological and yield contributing characters studied in inoculated and uninoculated plants in upland rice varieties (average of three replications).

\begin{tabular}{|c|c|c|c|c|c|c|c|c|c|c|c|c|c|c|}
\hline \multirow{2}{*}{ Variety } & \multicolumn{2}{|c|}{$\begin{array}{l}\% \text { seedling } \\
\text { infection }\end{array}$} & \multicolumn{2}{|c|}{$\begin{array}{l}\text { Plant height } \\
\text { (cm) }\end{array}$} & \multicolumn{2}{|c|}{$\begin{array}{c}\text { No. of tillers/ } \\
\text { hill }\end{array}$} & \multicolumn{2}{|c|}{$\begin{array}{c}\text { No. of panicles/ } \\
\text { hill }\end{array}$} & \multicolumn{2}{|c|}{$\begin{array}{l}\text { Panicle length } \\
(\mathrm{cm})\end{array}$} & \multicolumn{2}{|c|}{$\begin{array}{l}\text { No. of filled } \\
\text { grains/panicle }\end{array}$} & \multicolumn{2}{|c|}{ Yield (g/plant) } \\
\hline & Ino & Con & Ino & Con & Ino & Con & Ino & Con & Ino & Con & Ino & Con & Ino & Con \\
\hline Purbachi & 90.39 & 0.00 & 37.39 & 78.24 & 16.07 & 16.70 & 7.34 & 12.67 & 20.61 & 23.66 & 72.33 & 134.22 & 5.00 & 19.50 \\
\hline Kumragoir & 0.00 & 0.00 & 138.33 & 143.89 & 16.63 & 15.93 & 11.67 & 15.56 & 27.56 & 28.93 & 117.78 & 144.00 & 50.00 & 62.00 \\
\hline BR8 & 76.74 & 0.00 & 45.76 & 92.13 & 7.77 & 10.37 & 4.33 & 7.78 & 18.63 & 21.79 & 76.00 & 52.22 & 10.82 & 18.33 \\
\hline BR26 & 91.59 & 0.00 & 33.71 & 74.50 & 12.67 & 10.77 & 3.55 & 11.67 & 19.29 & 22.91 & 68.56 & 91.22 & 3.42 & 9.22 \\
\hline BRRI dhan27 & 93.39 & 0.00 & 48.13 & 102.16 & 6.83 & 6.47 & 4.34 & 6.78 & 20.99 & 24.63 & 63.44 & 83.22 & 3.17 & 6.91 \\
\hline BRRI dhan 42 & 83.33 & 0.00 & 44.12 & 83.73 & 10.10 & 12.90 & 5.86 & 8.78 & 19.16 & 22.58 & 75.44 & 83.44 & 6.37 & 11.63 \\
\hline BRRI dhan 43 & 91.91 & 0.00 & 41.71 & 76.13 & 11.07 & 11.47 & 7.44 & 10.33 & 20.46 & 22.69 & 67.89 & 69.22 & 5.51 & 12.13 \\
\hline BRRI dhan 48 & 89.09 & 0.00 & 34.10 & 75.30 & 14.80 & 13.30 & 8.56 & 11.00 & 21.71 & 23.46 & 51.33 & 116.22 & 5.45 & 14.12 \\
\hline CV (\%) & \multicolumn{2}{|c|}{17.35} & \multicolumn{2}{|c|}{30.95} & \multicolumn{2}{|c|}{17.83} & \multicolumn{2}{|c|}{27.41} & \multicolumn{2}{|c|}{1.17} & \multicolumn{2}{|c|}{19.11} & \multicolumn{2}{|c|}{6.37} \\
\hline
\end{tabular}

Ino: inoculated plants (treated plants) and Con: control plants (uninoculated plants).

$74.50 \mathrm{~cm}$, a reduction of $54.75 \%$ compared to a $52.2 \%$ reduction in the susceptible check Purbachi. The lowest $\mathrm{PH}$ reduction was found in BRRI dhan43 (45.21\%). In the resistant check Kumragoir PH reduction in inoculated plants was only $3.86 \%$ compared to control plants. In case of number of tillers/hill the variety BRRI dhan48 (14.80) produced more tillers among tested varieties in inoculated plants and BRRI dhan27 (6.83) produced less number of tillers/ 


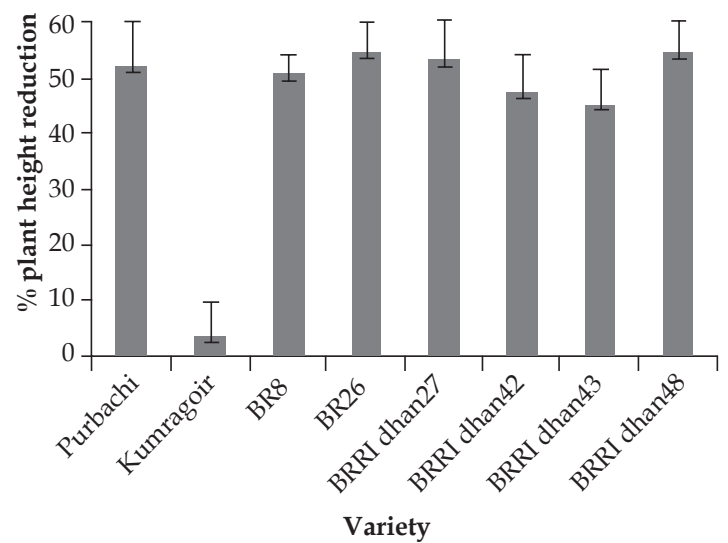

Fig. 1. Percent reduction of plant height in inoculated over control plants (upland).

hill. In control plants these two varieties had also the highest and lowest number of tillers/ hill (13.30 and 6.47) respectively. Varieties BR26, BRRI dhan27 and BRRI dhan48 had more tillers/hill in inoculated plants than control plants (Table 3 ).

\section{Yield data}

The panicle numbers/hill was higher in control plants than inoculated plants for all the tested varieties. Reduction of panicle number was the lowest in BRRI dhan 48 $(22.18 \%)$ followed by BRRI dhan43 (27.98\%) and BRRI dhan42 (33.26\%) (Fig. 2). The highest percent of panicle panicle number reduction was observed in BR26 (69.58\%) followed by BR8 (44.34\%) and BRRI dhan27 (35.99\%). The variety BRRI dhan48 (22.18\%) showed lower panicle number reduction than the resistant check Kumragoir (25.00\%) and the variety BR26 (69.58\%) had higher basical number reduction than the susceptible check Purbachi $(42.07 \%)$. The panicle length (PL), number of filled grains/panicle and yield (g/plant) were found to vary from $18.63 \mathrm{~cm}, 51.33$ and $3.17 \mathrm{~g} /$ plant for the varieties BR8, BRRI dhan48, BRRI dhan27 to $21.71 \mathrm{~cm}, 76.00$ and $10.82 \mathrm{~g} /$ plant for the varieties BRRI dhan48, BR8 and BR8 respectively in inoculated plants. On the other hand, in control plants these values ranged from $21.79 \mathrm{~cm}, 52.22$ and $6.91 \mathrm{~g} /$ plant for the

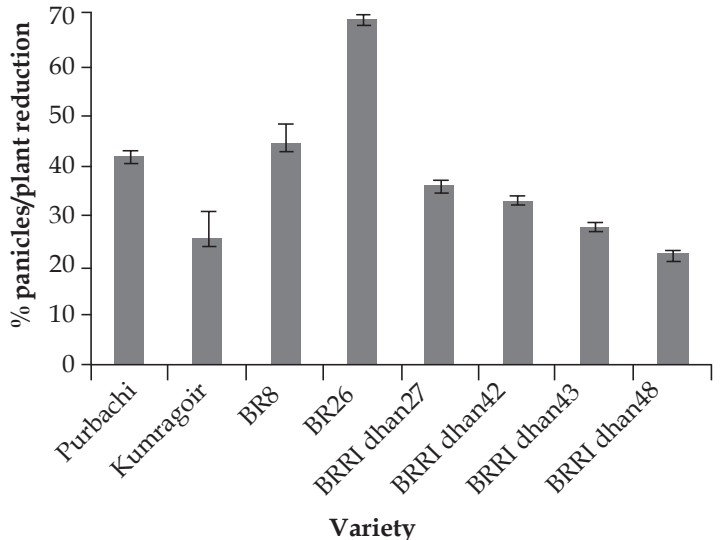

Fig. 2. Percent reduction of panicle numbers/hill in inoculated over control plants (upland).

varieties BR8, BR8 and BRRI dhan 27 to $24.63 \mathrm{~cm}$, 116.22 and $18.33 \mathrm{~g} /$ plant for the varieties BRRI dhan27, BRRI dhan 48 and BR8 respectively. Of tested varieties under upland conditions, the highest PL reduction was observed in BR26 (15.80\%) followed by BRRI dhan42 (15.15\%), BRRI dhan27 (14.78\%) and BR8 (14.50\%); and the lowest was in the variety BRRI dhan 48 (7.46\%) (Fig. 3). Number of filled grains/panicle (FG/P) was also higher in control plot than inoculated one for all the tested varieties except BR8. All the eight varieties showed higher yield in control plot than inoculated plants. Percent yield reduction was varied from 40.97 to 62.91 in the present study. The lowest yield reduction belonged to BR8 $(40.97 \%)$ while it was the highest for the variety BR26 (62.91\%) (Fig. 4). The other tested varieties BRRI dhan27, BRRI dhan42, BRRI dhan 43 and BRRI dhan 48 had the $54.12,45.23,54.58$ and $61.40 \%$ yield reduction respectively compared to control plants. The resistant check Kumragoir showed only 19.35\% and the susceptible check Purbachi exhibited $74.35 \%$ yield reduction in inoculated plants.

\section{Rainfed lowland rice}

Recovering data. The effect of variety and treatment was highly significant in the present study (Table 5). Among the ten varieties, seedlings of nine varieties were infected $100 \%$ by tungro disease after artificial inoculation except resistant variety Kumragoir. No disease 




Fig. 3. Percent reduction of panicle length in inoculated over control plants (upland).



Fig. 4. Percent reduction of yield in inoculated over control plants (upland).

symptoms were observed in Kumragoir. All the ten varieties showed higher $\mathrm{PH}$ in control than inoculated plants (Table 6). The lowest $\mathrm{PH}$ reduction was observed in BRRI dhan 46 $(4.45 \%)$, which was almost similar to resistant check Kumragoir (3.86\%) and the highest in the variety BRRI dhan33 (46.14\%) (Fig. 5). The BRRI dhan37, BRRI dhan38 and BRRI dhan46 showed resistant reaction, while BRRI dhan33 and BRRI dhan 40 revealed susceptible reaction against tungro disease in case of the character $\mathrm{PH}$.

\section{Yield data}

Although the variety BRRI dhan46 had higher panicle length in inoculated $(24.57 \mathrm{~cm})$ plants than control $(24.44 \mathrm{~cm})$, the difference was not significant. On the contrary, number of filled grains/panicle and yield/plant was higher in control plants for this variety. Panicle length reduction was the lowest in BRRI dhan37 $(0.32 \%)$ followed by BRRI dhan41 (3.21\%) and BRRI dhan39 (12.53\%) (Fig. 6). For the grain character number of filled grains/panicle was higher in healthy plants than diseased one for all the tested varieties. Reduction in filled grains/panicle of up to $100 \%$ was observed in

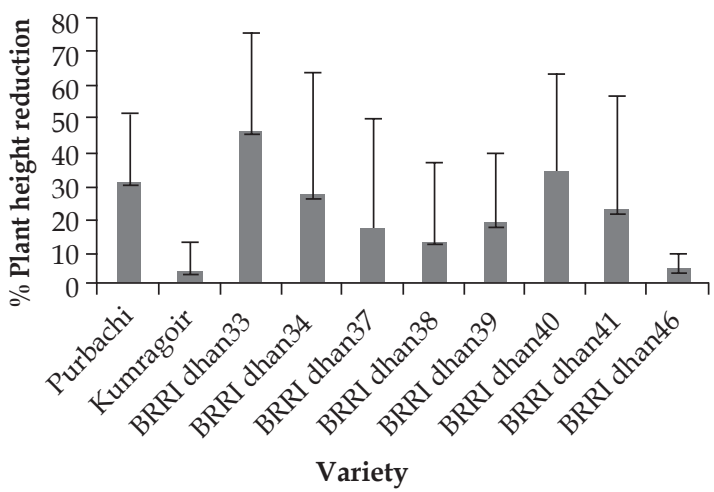

Fig. 5. Percent reduction of plant height in inoculated over control plants (rainfed lowland).

Table 5. Mean squares of analysis of variance for morphological and yield contributing characters studied in inoculated and uninoculated plants in lowland rice varieties.

\begin{tabular}{lcccccccc}
\hline SV & df & SI & PH & NT/H & NP/H & PL & FG/P & Y/P \\
\hline Block (B) & 2 & 0.00 & $14049.00^{* *}$ & $1.78^{\text {ns }}$ & $32.08^{*}$ & $0.08^{\text {ns }}$ & $802.91^{\text {ns }}$ & $0.71^{\text {ns }}$ \\
Variety (V) & 7 & $1500.00^{* *}$ & $3794.15^{* *}$ & $99.64^{* *}$ & $64.19^{* *}$ & $103.57^{* *}$ & $12310.51^{* *}$ & $1084.20^{* *}$ \\
Treatment (T) & 1 & $121500.00^{* *}$ & $3597.71^{* *}$ & $90.53^{* *}$ & $159.54^{* *}$ & $335.12^{* *}$ & $56765.12^{* *}$ & $291.06^{* *}$ \\
Var*Trt & 7 & $1500.00^{* *}$ & $101.74^{\text {ns }}$ & $21.10^{*}$ & $5.99^{\text {ns }}$ & $80.20^{* *}$ & $3672.22^{* *}$ & $196.89^{* *}$ \\
Error & 30 & $0.00^{* *}$ & 185.90 & 8.23 & 7.59 & 1.75 & 439.90 & 1.82 \\
\hline
\end{tabular}

$\mathrm{SV}$, source of variation; $\mathrm{df}$, degree of freedom; $\mathrm{SI}$, \% seedling infection; $\mathrm{PH}$, plant height $(\mathrm{cm})$; $\mathrm{NT} / \mathrm{H}$, total number of tillers plant $^{-1}, \mathrm{NP} / \mathrm{H}$, number of panicles/hill; PL, panicle length; FG/P, number of filled grains/panicle; $\mathrm{Y} / \mathrm{P}$, yield/plan $\mathrm{t}(\mathrm{g})$ *Significant at $5 \%$ level; **highly significant at $1 \%$ level; non significant. 
Table 6. Morphological and yield contributing characters studied in inoculated and uninoculated plants in lowland rainfed rice varieties (average of three replications).

\begin{tabular}{|c|c|c|c|c|c|c|c|c|c|c|c|c|c|c|}
\hline \multirow{2}{*}{ Variety } & \multicolumn{2}{|c|}{$\begin{array}{l}\% \text { seedling } \\
\text { infection }\end{array}$} & \multicolumn{2}{|c|}{ Plant height $(\mathrm{cm})$} & \multicolumn{2}{|c|}{ No. of tillers/hill } & \multicolumn{2}{|c|}{$\begin{array}{c}\text { No. of panicles/ } \\
\text { hill }\end{array}$} & \multicolumn{2}{|c|}{$\begin{array}{c}\text { Panicle length } \\
(\mathrm{cm})\end{array}$} & \multicolumn{2}{|c|}{$\begin{array}{l}\text { No. of filled } \\
\text { grains/panicle }\end{array}$} & \multicolumn{2}{|c|}{ Yield (g/plant) } \\
\hline & Ino & Con & Ino & Con & Ino & Con & Ino & Con & Ino & Con & Ino & Con & Ino & Con \\
\hline Purbachi & 100.00 & 0.00 & 43.35 & 62.09 & 6.33 & 17.10 & 6.33 & 8.56 & 19.21 & 21.00 & 42.44 & 87.67 & 8.89 & 12.00 \\
\hline Kumragoir & 0.00 & 0.00 & 135.30 & 140.50 & 15.03 & 14.53 & 10.67 & 14.60 & 14.40 & 26.40 & 113.50 & 141.45 & 45.00 & 53.50 \\
\hline BRRI dhan33 & 100.00 & 0.00 & 32.15 & 59.69 & 2.23 & 10.27 & 0.44 & 5.56 & 13.52 & 19.24 & 6.67 & 54.33 & 0.13 & 5.86 \\
\hline BRRI dhan 34 & 100.00 & 0.00 & 59.22 & 80.93 & 13.70 & 14.57 & 5.56 & 5.78 & 22.48 & 25.73 & 121.56 & 239.56 & 3.78 & 10.60 \\
\hline BRRI dhan 37 & 100.00 & 0.00 & 67.22 & 80.93 & 15.97 & 17.23 & 7.65 & 8.78 & 22.07 & 22.14 & 139.00 & 185.44 & 15.20 & 17.77 \\
\hline BRRI dhan 38 & 100.00 & 0.00 & 68.07 & 78.18 & 20.53 & 21.90 & 10.67 & 12.22 & 20.76 & 25.84 & 71.89 & 120.67 & 15.55 & 23.00 \\
\hline BRRI dhan 39 & 100.00 & 0.00 & 52.61 & 64.36 & 12.67 & 13.47 & 0.89 & 6.11 & 20.32 & 23.23 & 60.89 & 74.78 & 5.83 & 8.20 \\
\hline BRRI dhan 40 & 100.00 & 0.00 & 50.43 & 76.19 & 12.57 & 12.97 & 3.11 & 5.89 & 0.00 & 24.79 & 0.00 & 177.44 & 0.00 & 24.20 \\
\hline BRRI dhan 41 & 100.00 & 0.00 & 60.42 & 77.78 & 11.97 & 12.67 & 2.33 & 6.45 & 24.70 & 25.52 & 84.78 & 147.11 & 4.44 & 26.40 \\
\hline BRRI dhan 46 & 100.00 & 0.00 & 65.24 & 68.28 & 18.0 & 18.87 & 2.78 & 9.11 & 24.57 & 24.44 & 88.67 & 116.11 & 15.83 & 28.20 \\
\hline CV (\%) & \multicolumn{2}{|c|}{0.00} & \multicolumn{2}{|c|}{13.63} & \multicolumn{2}{|c|}{20.31} & \multicolumn{2}{|c|}{41.27} & \multicolumn{2}{|c|}{6.17} & \multicolumn{2}{|c|}{20.22} & \multicolumn{2}{|c|}{7.18} \\
\hline
\end{tabular}

Ino: inoculated plants (treated plants) and Con: control plants (uninoculated plants).

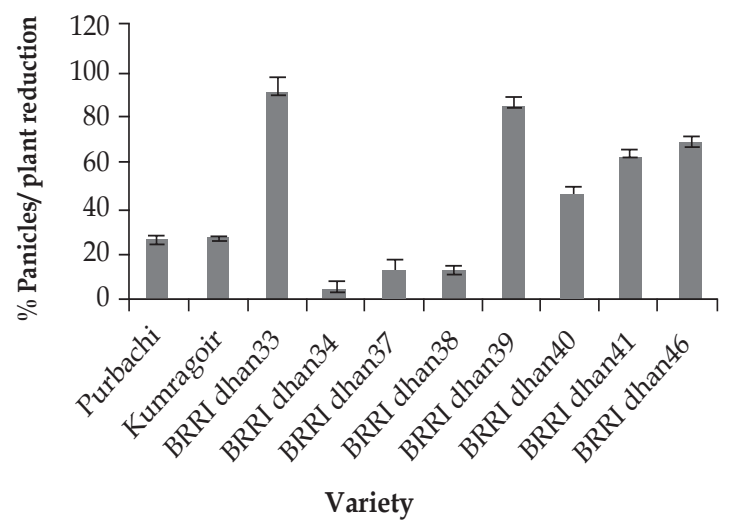

Fig. 6. Percent reduction of panicle numbers/hill in inoculated over control plants (rainfed lowland).

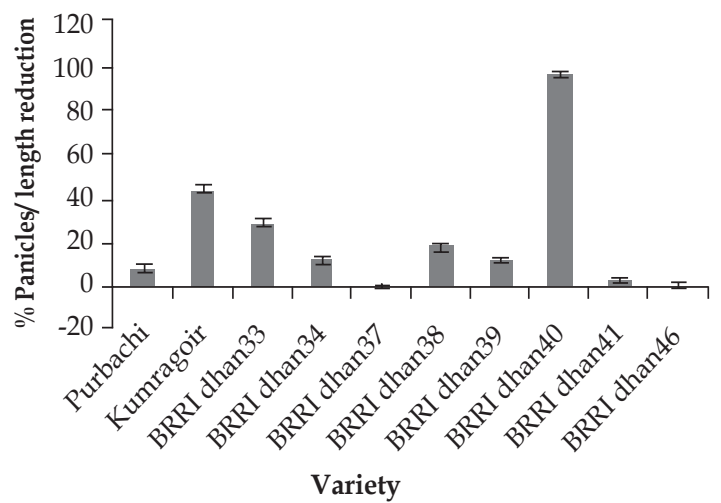

Fig. 7. Percent reduction of panicle length in inoculated over control plants (rainfed lowland). the variety BRRI dhan40 (Fig. 7). All the ten varieties showed higher yield in control plot than inoculated one. In lieu of yield, BRRI dhan37 (14.46\%) showed the lowest yield reduction. It showed even less yield reduction than the resistant check Kumragoir (15.89\%), simultaneously exhibited the highest recovering ability in lowland condition (Fig. 8). The BRRI dhan 33 and BRRI dhan 40 had $97.78 \%$ and $100 \%$ yield reduction revealed these varieties did not have any recovering ability under tungro disease infection.

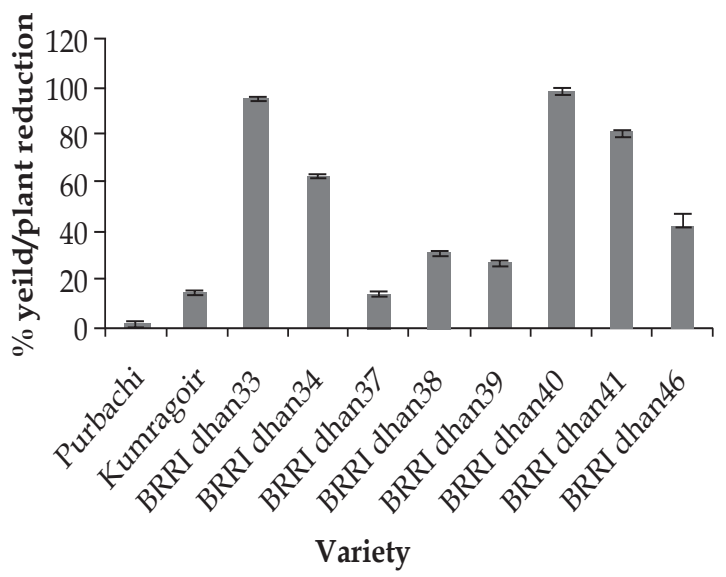

Fig. 8. Percent reduction of yield in inoculated over control plants (rainfed lowland). 


\section{DISCUSSION}

Yellow or orange-yellow discoloration of leaves, stunting of plant growth, reduction in number of effective tillers, shortness of panicle length, and often sterile or partial filled grains are the characteristics of tungro disease in rice. In our experiment, we observed these kinds of symptoms in all tested inoculated varieties. Some varieties exhibited severe, while others showed mild tungro symptoms after inoculation. However, the varieties which had recovering ability were recovered up to harvest stage while some varieties had very less ability to recover against tungro disease.

\section{Upland rice}

In upland rice, all varieties showed better results in healthy plants than diseased plants for the agronomic character $\mathrm{PH}$. It is supported by Agrios, 2005. He stated tungro-infected rice plants are stunted compared to healthy rice plants. Some varieties, such as Kumragoir, BR26, BRRI dhan27 and BRRI dhan 48 showed higher number of tillers/hill in diseased plants. In contrast, productive tillers were always higher in control plants than diseased treatment for all varieties. One of the characteristics of tungro disease is that the infected plants become bushy than uninfected plants. In this study, we observed this symptom in treated plants. Although diseased plants had more tillers but most of them were secondary and tertiary and so they did not bear any panicle. Panicle length was also higher in healthy plants for all varieties than diseased plants. The panicles of infected plants are often small, sterile and incompletely exerted (www. rkmp.co.in/cont/symptoms-of-rice-tungrodisease). All varieties showed higher number of filled grains/panicle in control plants than inoculated plants except BR8, which had more filled grains in diseased plants than healthy ones and consequently it showed lowest yield reduction and had highest recovering ability in terms of yield (g/plant). The BRRI dhan 42 and BRRI dhan 27 showed moderately tolerant reaction ie moderate recovering ability against tungro disease. During the screening of BRRI rice varieties Latif et al. (2011) also found the similar result for BRRI dhan27 as in the present study. Among tested varieties, BR26 exhibited the lowest recovering ability for the character yield/plant (g). The same result was also reported in a study conducted by BRRI (2000) that BR26 is susceptible to rice tungro disease.

\section{Rainfed lowland rice}

The BRRI dhan 33 and BRRI dhan 40 did not show any tolerance or recovering ability. BRRI dhan34 and BRRI dhan41 had some extent tolerance, which showed slight recovery against tungro. BRRI dhan37 and BRRI dhan39 exhibited more tolerance or higher recovering ability for both number of filled grains/panicle and yield (g/plant), although all these varieties seedlings were $100 \%$ tungro infected. In a similar study, Latif et al. (2011) found that BRRI dhan33 is moderately susceptible while BRRI dhan37 are moderately resistant against rice tungro disease. Among susceptible varieties, BRRI dhan40 did not produce any yield; although it had some panicles, all spikelets were sterile, which is one of the most prominent symptoms of tungro disease. In contrast, BRRI dhan37 showed strong recovering ability and the highest tolerance after 100\% seedlings being affected by tungro, which showed less reduction of number of panicles/hill, panicle length and yield ( $\mathrm{g} /$ plant), even than the resistant variety Kumragoir. Therefore, this variety could be used as a parental line in crossing programme for the development of tungro resistant varieties or could be used in tungro endemic areas where it would provide better yield although affected by tungro disease.

Resistant to tungro disease has been an important breeding objective for rice improvement in many Asian countries (Ling, 1974; Anjanejulu et al., 1982; Buddenhagen, 1983). Many cultivars bred as tungro-resistant had resistance to GLH (Rapusas and Heinrichs, 1982; Heinrichs and Rapusas, 1983; Hibino et al., 1987) and did not last long (Inoue and RuyAree, 1977; Manwan et al., 1985; Hibino et al., 1987; Dahal et al., 1990). High yielding cultivars 
with resistance to tungro have succumbed after a few years of intensive cultivation in Indonesia (Manwan et al., 1985;), Philippines (Hibino et al., 1987; Dahal et al., 1990) and Thailand (Inoue and Ruy-Aree, 1977). For this reason, it is pertinent to identify varieties with higher tolerance or high recovering ability. In the present case, all the varieties were artificially inoculated by viruliferous GLH. All varieties showed distinct tungro symptom after three weeks of inoculation and also after transplanting in the field. With the advancement of plant growth, varieties BR8 and BRRI dhan37 recovered from tungro syndrome due to their genetic makeup consisting tolerance potentiality showed better yield, while other varieties like BRRI dhan33 and BRRI dhan40 did not return any yield.

\section{CONCLUSION}

Among upland, BR8 and among lowland, BRRI dhan37 were identified as tolerant varieties, which exhibited highest recovering ability in respect to character number of panicles/hill, panicle length and yield (g/plant), could be cultivated in tungro disease endemic areas. In these studies, all test varieties were artificially inoculated by viruliferous GLH. All the varieties showed typical tungro symptom after 21 days of inoculation and also in the field. But with the progress of plant development, varieties BR8 and BRRI dhan37 recovered from tungro syndrome due to their genetic makeup consisting tolerance potentiality showed better yield, at the same time other varieties, for example, BRRI dhan 33 and BRRI dhan 40 had no yield return.

\section{ACKNOWLEDGEMENTS}

The authors sincerely express their gratitude to the authorities of Bangladesh Rice Research Institute (BRRI), and to Mr Md Ismail Hossain, staff of plant pathology for his help to rear and maintain the GLH in net house.

\section{REFERENCES}

Agrios, G N. 2005. Plant Pathology. $5^{\text {th }}$ edn. Elsevier Academic Press, Burlington, USA.

Anjanejulu, A, S K Singh and M M Shenoi. 1982. Evaluation of rice varieties for tungro resistance by field screening techniques. Tropical Pest Manag. 28: 147155.

Bangladesh Rice Research Institute (BRRI), Annual Report. 1983.

Bangladesh Rice Research Institute (BRRI). 2000. Adhunik dhaner chas" (modern rice cultivation), Gazipur-1701, Bangladesh.

Bergonia, H T. 1978. Control measure to prevent tungro virus out break. Plant Protection Newsletter. 7 (2): 4.

Buddenhagen, I W. 1983. Disease resistance in rice; In: Durable disease resistance in crops", Lamberti, F., Waller, J.M., eds. Vander Graaff N. V., Plenum, New York, pp. 401-428.

Cabunagan, R E, S Angeles and Vilareal. 1999. Multilocation evaluation of advanced breeding lines for resistance to rice tungro viruses. In: T.C.B. Chancellor, O. Azzam, K.L. Heong (Eds.), Rice Tungro Disease Management, International Rice Research Institute (IRRI), Los Banõs, Philippines, pp. 45-57.

Dahal, G, H Hibino, R C Cabunagan, E R Tiongco, Z M Flores and V Aguiero. 1990. Changes in cultivar relations to tungro due to changes in "Virulence" of the leafhopper vector. Phytopathol. 80: 659-665.

Dahal, G, I Dasgupta, G Lee and R Hull. 1992. Comparative transmission and varietal reaction to three isolates of rice tungro virus disease. Annals of App. Biol. 120: 287-300.

Dai, S and R N Beachy. 2009. Genetic engineering of rice to resist rice tungro disease. In Vitro Cell Dev, Biol. Plantarum. 45: 517-524.

H. Hibino, E R Tiongco, R C Cabunagan and Z M Flores. 1987. Resistance to rice tungro-associated virus in rice under experimental and natural conditions. Phytopathol. 77: 871-875.

Heinrichs, E A and H R Rapusa. 1983. Correlation of resistance to the green leafhopper, Nephotettix virescens, (Homoptera: Cicadellidae) with tungro virus infection in rice varieties having different genes for resistance, Environ. Entom. 12: 201-205.

Hibino, H, N Saleh and M Roech. 1979. Transmission of two kinds of rice tungro associated viruses by insect vectors. Phytopathology. 69: 1266-1268.

Hibino, H. 1983. Relations of rice tungro bacilliform and tungro spherical viruses with their vector Nephotettix virescens. Annals of the Phytopathol. Socie. of Japan. 49: 545-553. 
http:/ / www.rkmp.co.in/cont/symptoms-of-rice-tungrodisease

Inoue, H and S. Ruy-Aree. 1977. Bionomics of green leafhopper and epidemics of yellow orange leaf virus disease in Thailand. Tropical Agri. Res. Series.10: 117-121.

John, V T. 1968. Identification and characterization of tungro, a virus disease of rice in India. Plant Dis. Report. 52: 871-875.

Khush, G S and S S Virmani. 1985. Breeding for disease resistance; In: Progress in plant breeding, Rassel, I.G.F., ed. Blackwell publications, United Kingdom, pp. 239-279.

Khush, GS, E Angeles, P S Virk and D S Brar. 2004. Breeding rice for resistance to tungro virus at IRRI. SABRAO J. Breed. Genet. 36: 101-106.

Latif, M A, M A Badsha, M I Tajul, M S Kabir, M Y Rafii and M A T Mia. 2011. Identification of genotypes resistant to blast, bacterial leaf blight, sheath blight and tungro and efficacy of seed treating fungicides against blast disease of rice. Sci. Res. Essays. 6: 2804-2811.

Ling, K C. 1974. An improved mass screening methodfor testing the resistance of rice varieties to tungro disease in the greenhouse. Philippines Phytopathol. 10: 19-30.

Ling, K C. 1979. Rice Virus Diseases. $4^{\text {th }}$ edn. The International Rice Research Institute, Los Banõs Laguna, Philippines, p. 10.
Manwan, I, S Sama and S A Rizvi. 1985. Use of varietal rotation in the management of tungro disease in Indonesia. Indonesian J. Agril. Develop. 7: 43-48.

Miah, S A. 1984. Comments on RTV collaborative project, In: A Paper presented in International Rice Research Congress held at CRRI, Bhubaneswar, India, October, 1984.

Miah, S A. 1973. Present status of rice diseases; Country report and research notes on virus diseases. The Rice Pathology Newsletter. 2: 7.

Ou, S H, C T Rivera, S J Navarathan and K G Goh. 1965. Virus nature of Penyakit Merah disease of rice in Malaysia. Plant Dis. Report. 49: 778-782.

Ou, S H. 1984. Rice Diseas. $2^{\text {nd }}$ ed. CMI, Kew, Surrey, England, pp. 1-3.

Rapusa, H R and E A Heinrichs. 1982. Plant age and level of resistance to green Leafhopper, Nephotettix virescens, and tungro virus in rice varieties. Crop Prot. 1: 91-98.

Rivera, C T and S H Ou. 1965. Leafhopper transmission of tungro a disease of rice plant. Plant Dis. Repoter. 49:127-131.

Shibata, Y R C, P Q Cabunagan, I R Cabauatan and Choi. 2007. Characterization of Oryza rufipogon-derived resistance to tungro disease in rice. Plant Dis. 91: 1386-1391.

Zenna, N S, P Q Cabauatan, M H Baraoidan, I R Leung and Choi. 2008. Characterization of a putative rice mutant for reaction to rice tungro disease. Crop Sci. 48: 480-486. 